\title{
JUMLAH NEUTROFIL PADA PETANI TERPAPAR PESTISIDA DI KELURAHAN RURUKAN KECAMATAN TOMOHON TIMUR
}

\author{
Putu P. P. Nugraha, Hedison Polii, Herlina I. S. Wungouw \\ Bagian Fisiologi Fakultas Kedokteran Universitas Sam Ratulangi Manado \\ Email: Putu.nugraha@yahoo.com
}

\begin{abstract}
Neutrophil is a part of white blood cells that known as phagocyte cells and serves as the immunological defense systems which protect the human organism from the invading foreign objects. Pesticides are poisonous substances used to eradicate pests. One of the effects of pesticides exposure on health is impaired on blood profile. This study aimed to determine the neutrophils count in farmers that exposed to pesticides at Rurukan village, East Tomohon District. This study was conducted using cross sectional study plan. The research subjects were 50 people who have met the inclusion criteria. The neutrophil counts were measured using ABX Pentra XL 80. In this study, the mean of neutrophil counts were 3,850 cells $/ \mathrm{mm}^{3}$. It can be concluded most of the subjects had a neutrophil counts below the normal value.
\end{abstract}

Key words: Neutrophil, pesticides

Abstrak: Neutrofil adalah salah satu bagian dari sel darah putih yang merupakan sel spesialis fagositik dan berfungsi sebagai pertahanan pertama tubuh terhadap invasi suatu benda asing. Pestisida adalah suatu zat yang bersifat racun yang berfungsi untuk memberantas organisme pengganggu tanaman. Salah satu dampak dari paparan pestisida terhadap kesehatan yaitu gangguan pada profil darah. Penelitian ini bertujuan untuk mengetahui gambaran jumlah neutrofil pada petani terpapar pestisida di kelurahan Rurukan kecamatan Tomohon Timur. Penelitian ini dilakukan menggunakan rancangan potong lintang. Subyek penelitian berjumlah 50 responden. Jumlah neutrofil diukur menggunakan alat ABX Pentra XL 80. Hasil pada penelitian ini didapatkan rerata jumlah neutrofil subyek adalah $3.850 \mathrm{sel} / \mathrm{mm}^{3}$. Dapat disimpulkan bahwa sebagian besar subyek memiliki jumlah neutrofil di bawah nilai normal.

Kata Kunci: Neutrofil, pestisida

Indonesia merupakan negara agraris dimana sebagian besar penduduknya bekerja sebagai petani. Berdasarkan data Badan Pusat Statistik (BPS) Mei 2012 tenaga kerja di sektor pertanian mencapai 41,20 juta jiwa atau sekitar 43,4\% dari jumlah total penduduk Indonesia. Angka tersebut mengalami kenaikan sebesar 4,76\% atau sebesar 1,9 juta dibandingkan Agustus $2011^{1}$.

Pestisida merupakan suatu bahan kimia yang digunakan untuk membasmi organisme pengganggu atau hama. Pestisida dapat berupa insektisida untuk membasmi serangga, fungisida (jamur), rodentisida (hewan pengerat), herbisida (gulma), akarisida (tungau), dan bakterisida (bakteri) $^{2}$. Hingga tahun 2006, Jumlah pestisida yang terdaftar untuk pertanian mencapai 1.336 formulasi dan 402 bahan aktif pestisida yang digunakan untuk mengendalikan hama di Indonesia. Pestisida kimia berdampak buruk bagi kesehatan dan juga lingkungan. World Health Organization (WHO) memperkirakan ada sekitar 3 juta orang yang bekerja pada sektor pertanian di negara-negara berkembang terkena racun pestisida kimia dan sekitar 18 ribu orang diantaranya meninggal setiap tahunnya ${ }^{3}$. 
Jalur masuknya pestisida ke dalam tubuh dapat terjadi melalui tiga jalur pokok yaitu penetrasi melalui kulit (absorbsi kulit), absorbsi melalui paru (inhalasi), absorbsi melalui saluran pencernaan (ingesti). Bentuk pemaparan yang paling lazim adalah melalui inhalasi dan kulit, sementara keracunan yang tidak disengaja, paling sering terjadi melalui pemaparan dermal ${ }^{4}$.

Sel darah putih atau leukosit merupakan unit sistem pertahanan tubuh yang mobile. Jumlah total leukosit dalam keadaan normal berkisar 5.000-10.000 sel $/ \mathrm{mm}^{3}$ darah dengan rata-rata 7.000 $\mathrm{sel} / \mathrm{mm}^{3}$. Terdapat lima macam leukosit yang bisa ditemukan dalam darah. Kelima sel tersebut adalah nuetrofil, eosinofil, basofil, monosit dan limfosit ${ }^{5}$. Neutrofil berfungsi melindungi tubuh terhadap organisme penyusup seperti bakteri, virus atau partikel asing lainnya dengan cara menelan substansi tersebut. Proses menelan itu disebut fagositosis. Bakteri atau partikel asing yang masuk ke dalam tubuh akan ditempeli suatu antibodi sehingga sangat rentan terhadap fagositosis ${ }^{6}$.

Salah satu dampak dari paparan pestisida terhadap kesehatan yaitu gangguan pada profil darah. Profil darah merupakan salah satu komponen penting dalam penilaian kesehatan seseorang. Ada berbagai faktor yang dapat mempengaruhi profil darah seseorang diantaranya umur, jenis kelamin, etnis, status gizi, dan lingkungan. Pestisida diperkirakan sebagai salah satu faktor lingkungan yang turut mempengaruhi profil darah. Beberapa penelitian menunjukan adanya pengaruh paparan pestisida terhadap profil darah ${ }^{7}$.

Berdasarkan uraian di atas maka penulis tertarik untuk meneliti jumlah neutrofil pada petani terpapar pestisida di kelurahan Rurukan kecamatan Tomohon Timur.

\section{METODE PENELITIAN}

Penelitian ini merupakan penelitian deskriptif dengan pendekatan cross sectional study. Pelaksanaan penelitian dilakukan pada bulan November-Desember 2013 yang bertempat di kelurahan Rurukan kecamatan Tomohon Timur. Populasi dalam penelitian ini adalah petani penyemprot pestisida di kelurahan Rurukan. Teknik pengambilan sampel dilakukan dengan purposive sampling dengan pertimbangan mereka yang mau berpartisipasi pada pemeriksaan jumlah neutrofil, dengan kriteria inklusi antara lain: berprofesi sebagai petani yang menggunakan pestisida, telah menggunakan pestisida minimal selama 5 tahun, tidak sedang mengidap penyakit infeksi dan bersedia menjadi subyek penelitian.

Pemeriksaan jumlah neutrofil menggunakan metode hitung jenis leukosit dengan bantuan alat ABX Pentra XL 80 kemudian hasilnya diinterpretasikan sebagai berikut:

a. Normal (5000-7000sel $\left./ \mathrm{mm}^{3}\right)$

b. Meningkat $\left(>7000 \mathrm{sel} / \mathrm{mm}^{3}\right)$

c. Menurun $\left(<5000 \mathrm{sel} / \mathrm{mm}^{3}\right)$

Data yang diperoleh dari hasil pemeriksaan neutrofil kemudian di sajikan dalam bentuk tabel distribusi frekuensi untuk mendapatkan gambaran jumlah neutrofil pada petani terpapar pestisida di kelurahan Rurukan kecamatan Tomohon Timur.

\section{HASIL PENELITIAN}

\section{Keadaan geografi tempat penelitian}

Daerah pertanian yang menjadi objek penelitian adalah Kelurahan Rurukan yang terletak di kecamatan Tomohon Timur. Kelurahan Rurukan berada pada dataran tinggi di lereng gunung Mahawu dengan luas wilayah 350 ha dan memiliki hamparan kebun pertanian yang dikelola oleh penduduk setempat secara tradisional. 
Batas wilayah Kelurahan Rurukan yaitu:

a. Sebelah Barat : Berbatasan dengan kelurahan Paslaten dan Talete.

b. Sebelah Timur : Berbatasan dengan Tondano.

c. Sebelah Selatan : Berbatasan dengan Rurukan 1.

d. Sebelah Utara : Berbatasan dengan Kumelembuai.

Jumlah penduduk Kelurahan Rurukan menurut data sensus penduduk pada tahun 2011 yaitu 1,763 jiwa dengan penduduk yang berjenis kelamin laki-laki sebanyak 920 jiwa dan 843 jiwa yang berjenis kelamin perempuan.

\section{Karakteristik subyek penelitian}

Pada penelitian ini digunakan subyek penelitian sebanyak 50 orang petani yang menggunakan pestisida dalam mengolah kebunnya.

Tabel 1. Karakteristik subyek menurut kelompok umur.

\begin{tabular}{llll}
\hline Umur & Frekuensi & Persentase $(\%)$ & $\begin{array}{l}\text { Rata-rata jumlah neutrofil } \\
\left(10^{3} \mathrm{sel} / \mathrm{mm}^{3}\right)\end{array}$ \\
\hline $25-40$ & 7 & 14 & 4.15 \\
$41-60$ & 34 & 68 & 3.79 \\
$61-75$ & 9 & 18 & 3.85 \\
\hline Total & 50 & 100 & 15.79 \\
\hline
\end{tabular}

Berdasarkan tabel 1 di atas dapat diketahui jumlah sampel menurut kelompok umur yang paling banyak adalah kelompok umur 41 - 60 tahun yaitu 33 subyek (68\%) dengan jumlah neutrofil rata-rata $3.790 \mathrm{sel} / \mathrm{mm}^{3}$, kemudian umur 61 - 75 tahun sebanyak 10 subyek (18\%) dengan jumlah neutrofil rata-rata $3.850 \mathrm{sel} / \mathrm{mm}^{3}$ dan yang paling sedikit adalah umur $25-40$ tahun sebanyak 7 subyek (14\%) dengan jumlah neutrofil rata-rata $4.150 \mathrm{sel} / \mathrm{mm}^{3}$.

Tabel 2. Karakteristik subyek menurut jenis kelamin.

\begin{tabular}{llll}
\hline Jenis kelamin & Frekuensi & Persentase (\%) & $\begin{array}{l}\text { Rata-rata jumlah neutrofil } \\
\left(10^{3} \mathrm{sel} / \mathrm{mm}^{3}\right)\end{array}$ \\
\hline Laki - laki & 26 & 52 & 4.080 \\
Perempuan & 24 & 48 & 3.500 \\
\hline Total & 50 & 100 & 7.580 \\
\hline
\end{tabular}

Berdasarkan tabel 2 di atas dapat diketahui jumlah sampel yang berjenis kelamin laki-laki yaitu 26 subyek (52\%) dengan rata- rata jumlah neutrofil $4.080 \mathrm{sel} / \mathrm{mm}^{3}$ dan jenis kelamin perempuan yaitu 24 subyek (48\%) dengan rata-rata jumlah neutrofil sebesar $3.500 \mathrm{sel} / \mathrm{mm}^{3}$.

Tabel 3. Distribusi jumlah neutrofil

\begin{tabular}{llll}
\hline Jumlah sampel & $\begin{array}{l}\text { Rata-rata } \\
\left(10^{3} \mathrm{sel} / \mathrm{mm}^{3}\right)\end{array}$ & $\begin{array}{l}\text { Nilai tertinggi } \\
\left(10^{3} \mathrm{sel} / \mathrm{mm}^{3}\right)\end{array}$ & $\begin{array}{l}\text { Nilai terendah } \\
\left(10^{3} \mathrm{sel} / \mathrm{mm}^{3}\right)\end{array}$ \\
\hline 50 & 3.850 & 8.250 & 1.410 \\
\hline
\end{tabular}

Berdasarkan data yang tertera pada tabel 3 di atas dapat dilihat bahwa, dari 50 sampel penelitian terdapat nilai rata-rata jumlah neutrofil sebesar $3.850 \mathrm{sel} / \mathrm{mm}^{3}$, dengan nilai tertinggi $8.250 \mathrm{sel} / \mathrm{mm}^{3}$, nilai terendah $1.410 \mathrm{sel} / \mathrm{mm}^{3}$. 
Tabel 4. Interpretasi jumlah neutrofil

\begin{tabular}{lll}
\hline Interpretasi jumlah neutrofil & Frekuensi & Persentase (\%) \\
\hline Menurun $\left(<5000 \mathrm{sel} / \mathrm{mm}^{3}\right)$ & 41 & 82 \\
Normal $\left(5000-7000 \mathrm{sel} / \mathrm{mm}^{3}\right)$ & 8 & 16 \\
Meningkat $\left(>7000 \mathrm{sel} / \mathrm{mm}^{3}\right)$ & 1 & 2 \\
\hline Total & 50 & 100 \\
\hline
\end{tabular}

Berdasarkan tabel 4 dapat dilihat bahwa jumlah neutrofil yang tergolong menurun sebanyak 41 subyek (82\%), tergolong normal 8 subyek (16\%) dan meningkat 1 subyek (2\%).

\section{PEMBAHASAN}

Hasil penelitian memperlihatkan sebanyak 41 orang subyek (82\%) mengalami penurunan jumlah neutrofil, 8 orang subyek (16 \%) memiliki jumlah neutrofil normal dan 1 orang subyek (2\%) mengalami peningkatan jumlah neutrofil. Pada penelitian ini didapatkan rata-rata jumlah neutrofil subyek yaitu sebesar $3.850 \mathrm{sel} / \mathrm{mm}^{3}$ yang dapat dilihat pada tabel 3, hal ini menunjukkan bahwa sebagian besar subyek memiliki jumlah neutrofil yang berada dibawah nilai normal. Hasil penelitian ini sejalan dengan penelitian yang dilakukan oleh Azmi yang membandingkan parameter darah pada petani terpapar pestisida dan darah orang normal di Pakistan, hasilnya menunjukan rata - rata jumlah neutrofil petani lebih rendah daripada orang normal $^{8}$.

Berdasarkan distribusi menurut kelompok umur, 7 subyek (14\%) yang berada pada kelompok umur 25-40 tahun memiliki jumlah neutrofil rata-rata $4.150 \mathrm{sel} / \mathrm{mm}^{3}$, 34 subyek (68\%) berada pada kelompok umur 41-60 tahun memiliki jumlah neutrofil rata-rata $3.790 \mathrm{sel} / \mathrm{mm}^{3}$ dan 9 subyek (18\%) yang berada pada kelompok umur 61-75 tahun memiliki jumlah neutrofil rata-rata $3.850 \mathrm{sel} / \mathrm{mm}^{3}$. Dari data tersebut dapat dilihat bahwa semua kelompok umur masih memiliki jumlah neutrofil rata-rata dibawah nilai normal.

Pada penelitian ini diperoleh data 26 subyek (52\%) berjenis kelamin laki-laki memiliki jumlah neutrofil rata-rata $4.080 \mathrm{sel} / \mathrm{mm}^{3}$ dan 24 subyek (48\%) berjenis kelamin perempuan memiliki jumlah neutrofil rata-rata $3.500 \mathrm{sel} / \mathrm{mm}^{3}$. Hal ini menyatakan bahwa subyek yang berjenis kelamin laki-laki maupun perempuan masih memiliki rata-rata jumlah neutrofil di bawah normal. Berbeda dengan penelitian yang dilakukan oleh Marinajati tentang hubungan riwayat paparan pestisida dengan profil darah pada wanita usia subur di daerah pertanian yang menyatakan bahwa tidak terdapat hubungan antara paparan pestisida dengan jumlah neutrofil. Hal ini mungkin disebabkan karna perbedaan intensitas paparan pestisida dan jenis pestisida yang digunakan. Keterlibatan wanita usia subur dalam pertanian yaitu mencabut rumput, menanam, memanen dan mencari hama. Selain itu, tidak jarang kegiatan penyemprotan pestisida dilakukan pada saat wanita usia subur sedang melakukan aktivitas di pertanian tersebut ${ }^{7}$.

Savithri melakukan penelitian pada profil darah tikus terpapar pestisida yang menunjukan terjadi penurunan persentase jumlah neutrofil. Pada penelitian tersebut, tikus dibagi dalam 4 kelompok dan masing-masing kelompok terdiri dari 10 ekor tikus. Kelompok pertama merupakan kontrol dan kelompok 2, 3, 4 diberikan pestisida chlorpyripos dengan dosis yang berbeda selama 7 hari. Hasilnya menunjukan terjadi penurunan yang signifikan pada sel darah merah, hemoglobin, hematokrit, mean corpuscular volume (MCV), mean corpuscular hemoglobin $(\mathrm{MCH})$ dan neutrofil. Neutrofil tikus diduga terlibat dalam memfagosit pestisida selama terjadi intoksikasi, yang kemudian neutrofil itu sendiri akan hancur akibat toksik dari pestisida. Hal ini yang mungkin menyebabkan penurunan jumlah neutrofil ${ }^{9}$. 
Penelitian pada petani di Polandia menunjukan bahwa pestisida dapat merusak fungsi neutrofil. Para petani tersebut memiliki indikasi gejala supresi fungsi neutrofil, seperti infeksi saluran nafas atas yang mana berkolerasi dengan durasi paparan pestisida. Walaupun infeksi saluran pernafasan atas berhubungan dengan paparan pestisida, tetapi mekanisme patologinya belum diketahui secara pasti ${ }^{10}$.

Pada penelitian ini didapatkan jumlah neutrofil yang paling tinggi diantara para subyek yaitu $8.250 \mathrm{sel} / \mathrm{mm}^{3}$, sedangkan jumlah neutrofil yang paling rendah yaitu $1.410 \mathrm{sel} / \mathrm{mm}^{3}$ dengan jumlah neutrofil rata-rata subyek yaitu $3.850 \mathrm{sel} / \mathrm{mm}^{3}$. Jadi, sebagian besar subyek memiliki jumlah neutrofil dibawah nilai normal. Penurunan jumlah neutrofil dapat terjadi akibat paparan zat kimia, contohnya pestisida yang bisa menurunkan fungsi neutrofil dan makrofag. Hal ini dapat menyebabkan penurunan sistem imun yang berhubungan dengan infeksi saluran nafas atas, sinusitis dan bronkhitis ${ }^{11}$.

\section{SIMPULAN}

Berdasarkan penelitian yang dilakukan pada 50 sampel darah petani di Kelurahan Rurukan didapatkan rerata jumlah neutrofil $3.850 \mathrm{sel} / \mathrm{mm}^{3}$. Hal ini dapat disimpulkan bahwa sebagian besar subyek memiliki jumlah neutrofil di bawah nilai normal.

\section{DAFTAR PUSTAKA}

1. Nugrayasa O. Tantangan dan peluang sektor pertanian 2013. 1 april 2013. Diakses tanggal 10 september 2013. Available from: http:/setgab.go.id/en/ artikel-6907 tantangan-dan-peluang-sektor-pertanian-2013.html.

2. Raini, M. Toksikologi insektisida rumah tangga dan pencegahan keracunan. Media Penelitian dan Pengembangan Kesehatan 2009;XIX Sup II:27-33.

3. Pentingnya analisis residu pestisida. 9 agustus 2012. Diakses tanggal 10 september 2013. Available from: http: pertaniansehat.com/read/2012/08/09/ pentingnya-analisis-residupestisida.html.

4. Ester M. Bahaya bahan kimia pada kesehatan manusia dan lingkungan. Jakarta: EGC;2006. h.38.

5. Sherwood L. Darah. Dalam: Santoso B, editor. Fisiologi manusia dari sel ke sistem. Edisi ke-2. Jakarta: EGC; 2001. h. 354-6.

6. Guyton A , Hall J. Pertahanan tubuh terhadap infeksi. Dalam: Rachman L, editor. Buku ajar fisiologi kedokteran. Edisi ke-11. Jakarta: EGC; 2008. h. 350-2.

7. Marinajati D, Endah N, Suhartono. Hubungan riwayat paparan pestisida dengan profil darah pada wanita usia subur di daerah pertanian cabai dan bawang merah. Jurnal Kesehatan Lingkungan Indonesia. 2012;11:61-7.

8. Azmi M, Naqvi S, Akhtar K, Moinuddin, Parveen S, Parveen R, et al. Effect of pesticide residues on health and blood parameters of farm workers from rural Gudap, Karachi, Pakistan. Journal of Environmental Biology. 2009:748-56.

9. Savithri Y, Sekhar P, Doss J. Changes in hematological profiles of albino rats under chlorpyrifos. International Journal of Pharma and Bio Sciences. 2010;1:1-7.

10. Repetto R, Baliga S. pesticide and the immune system: the public health risk. World Resources Institute; 1996. h. 44-5.

11. Hanson L, Ritter L. Toxicity and safety evaluation of pesticides. In: Doull J, Hemmen J, Hodgson E, Maibach H, Reiter L, Ritter L,et al editors. Hayes' handbook of pesticide toxicology. $3^{\text {rd }}$ ed. USA: Elsevier;2010. p. 484-5. 